\title{
A Review of Literature on Residential Solid Fuel Burning, and Consequently the Implications of Meeting the European 2050 Low-Carbon Targets
}

\author{
K. L. Rainey, M. Vaganay, S. MacIntyre \\ School of the Built Environment, Ulster University, Jordanstown, Northern Ireland \\ Email: rainey-k@email.ulster.ac.uk
}

Received 7 December 2015; accepted 6 April 2016; published 11 April 2016

\begin{abstract}
This paper is intended to source literature, identifying the adverse impacts on human health, from the pollutants released from residential burning from both fossil fuel and biomass sources. The literature sourced was ascertained through the conduction of a systematic literature review. The author assessed peer-reviewed English language articles, which had been published within the last five years. The studies reviewed indicated a clear increase in the burning of residential solid fuels. The findings suggest that residential solid fuel combustion is occurring in developed countries, primarily as a secondary source of heating during the winter months. The study concluded that similarly to bituminous coal, the domestic burning of wood also had adverse effects on human health. The intentions of UK Climate Change Act 2008 are to achieve an $80 \%$ reduction by the year 2050 in the net carbon account from the 1990 baseline. It is recommended for countries to meet the European 2050 targets, long-term measures need to be adopted. This includes switching from residential solid fuel burning to heating methods such as oil and gas, which are necessary in improving overall air quality and public health.
\end{abstract}

\section{Keywords}

Residential Solid Fuel, Health Impacts, Developed Countries, Air Pollutants, Climate Change

\section{Introduction}

In 2010 and 2012, the European Environment Agency (EEA) attributed more than 400,000 premature deaths, throughout Europe to the inhalation of air pollutants [1]. The combustion of residential solid fuels releases air pollutants such as $\mathrm{PM}_{10}, \mathrm{PM}_{2.5}$, benzo[a]pyrene and sulphur dioxide, concurring with the EEA, research studies [2] [3] suggest that these pollutants have adverse effects on human health. It has been established that the impacts from residential solid fuel combustion are comparable to that of pollution emitted from traffic on a busy street [4]. However, conclusive evidence from research studies of the impacts on human health from the com- 
bustion of residential solid fuel is limited. Due to the extensive variety of contributing sources to air pollution, the definitive source of exposure can be difficult to evidence [5]. The aim of the systematic literature review is to identify current studies which assess the health impacts from pollutants that are released from residential solid fuel combustion from open fire places and/or wood burning stoves, namely $\mathrm{PM}_{10}, \mathrm{PM}_{2.5}$, benzo[a]pyrene and sulphur dioxide within developed countries. In addition, this research intends to source whether residential solid fuel trends can be classified as seasonal specific. Furthermore, this paper critically reviews these studies, establishing whether the development of low-carbon energy supplies is achievable without having a detrimental effect on human health. Currently, the majority of developed countries are highly dependent on fossil fuels to placate the countries' high energy needs. Governmental climate change policy encouraging renewable, sustainable, energy sources and the reduction in greenhouse gas emission aims to eliminate this dependency [6]. Targets have been established by the European Union to increase renewable energy. One key target is $27 \%$ of the total energy consumption to be from renewable sources by the year 2030 [7]. Meeting the targets of the Climate Change Act 2008, the utilization of biomass energy production is encouraged, as biomass sources are deemed to be carbon neutral [8]. Air pollution should not be regarded as a local problem. Governmental action must be taken both nationally and even globally to reduce the impact that pollutants from residential solid fuel burning are having on public health [9]. Various studies [10]-[12] have found that the occurrence of European residential solid fuel burning is seasonal specific, occurring mainly on evenings and weekends during the winter months.

\section{Methods}

The collation of literature for analysis was sourced from; Science Direct, Scopus and from Pro Quest Health and Medical databases. When conducting the systematic literature review search, the selected articles were limited to peer-reviewed articles which had been published within the last five years in the English language. Figure 1 summarises the search strategy that was explored during the literature search. The search strategy key words comprised of exposure to pollutants from residential solid fuel burning, the health outcomes consequential from those pollutants, the source of the pollutants and the location of these studies. Articles which focused on residential solid fuel burning for cooking appliances were excluded. Studies within an area of high traffic levels or industry were also eliminated. The remaining articles which met the literature review criteria, and which could access the articles full text were reviewed by the author.

\section{Results and Discussion}

The preliminary search strategy key words retrieved 3606 potential articles for the author to review from the selected databases. Only 313 articles met the criteria of focusing on developed countries. Upon further review of these articles, 285 articles were excluded due to the absence of impacts on human health directly occurring from residential solid fuel burning from open fires and/or wood burning stoves. The remaining 28 articles were critically analysed by the author. Each of the articles focused on various pollutants, which the study examined 8 $\mathrm{PM}_{10}$ studies, $7 \mathrm{PM}_{2.5}$ studies, 10 benzo[a]pyrene studies and 3 sulphur dioxide studies. The systematic review of literature found that studies sampling particulate matter and benzo[a]pyrene have been more prevalent in recent years in comparison to sulphur dioxide. Benzo[a]pyrene has recently been found to be carcinogenic, accordingly current research studies [13]-[16] have focused on this pollutant with the intention to increase the body of knowledge. Similarly $\mathrm{PM}_{2.5}$ has only recently been focused upon with the European Council Directive

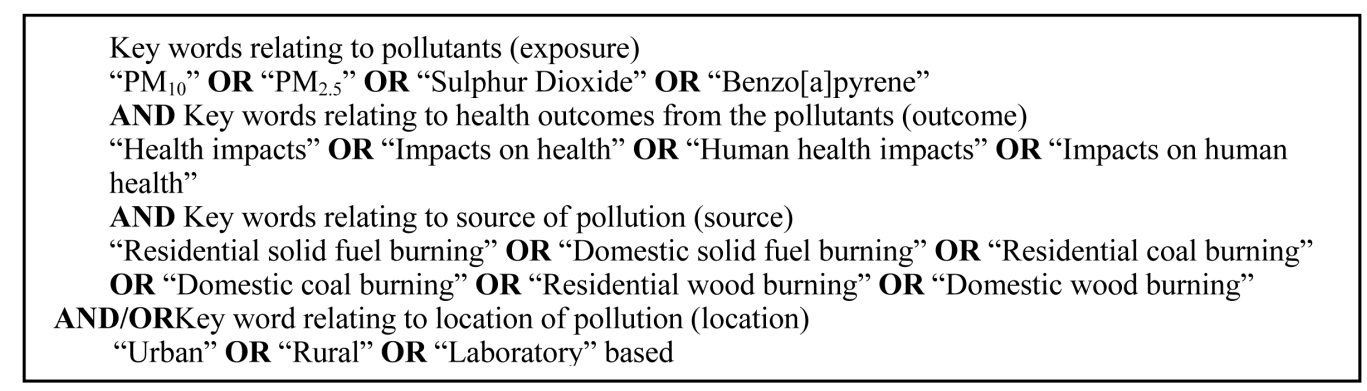

Figure 1. Search strategy used to identify, included studies for systematic literature review. 
(2008/50/EC) introducing new provisions, due to improved scientific understanding to the adverse health effects, $\mathrm{PM}_{2.5}$ has on human health [10]. In comparison to $\mathrm{PM}_{10}$, which when inhaled can enter into the upper human respiratory tract, $\mathrm{PM}_{2.5}$ particles are smaller, thus allowing them to infiltrate deeper into the lungs.

\subsection{Health Impacts}

Of the 28 articles reviewed by the author, only eight of those were directly associating the study to the adverse effects on human health, as a result of the contribution from residential solid fuel burning. The reviewed literature suggests that exposure to pollutants released from small-scale biomass and fossil fuel combustion devices, have been considered worldwide, to be negatively impacting upon human health [9]. Recently there has been increasing evidence, including human exposure studies [4] [17]. The studies have supported theories that exposure from residential solid fuel combustion has adverse effects on the health of the human population [18] [19]. Wood is a renewable source of residential heating. Although there are benefits to be gained from using wood as a means to heat the home, unregulated wood stoves can cause detrimental effects on human health [20]. The impact on human health from the shift from light fuel oil to solid fuel combustion, primarily wood, will be gradual. The chronic impacts on human health shall not automatically become apparent. However, over years of exposure, the inhalant will accumulate the pollutants, impacting on morbidity and mortality later on in life [20]. However, acute respiratory exposure can be associated with domestic solid fuel burning. The inhalation of pollutants from residential solid fuel combustion can cause both acute and chronic symptoms, affecting the inhalant in both the short and long term of their health condition [21].

\subsubsection{Impacts on the Respiratory System and Risk of Developing Cancer}

Research evaluating the ban on the sale of coal correlated black smoke concentrations with respiratory and cardiovascular deaths, as the average black smoke declined, the standardized respiratory and cardiovascular death rates coincided [17]. The assessment of pulmonary inflammation and tissue damage in the mouse lung from exposure to samples of particulate matter from either an old or modern domestic heating appliance indicated that mice exposed to the different heating appliances displayed differing effects. The modern heating appliances produced less particulate matter, conversely, the modern heating appliances induced the highest inflammatory, cytotoxic and genotoxic activities in the mice lungs [4]. These studies [4] [17], evidenced the relationship between, pollutants resultant from residential solid fuel burning and adverse effects on the human respiratory system. Benzo[a]pyrene is the only polycyclic hydrocarbon that has been categorized as a carcinogen by the International Agency for Research on Cancer [22]. Resultant from increasing expenses of energy, an increasing trend of residential solid fuel combustion is occurring during the winter months. A study [14] conducted evidenced, within both cities sampled the concentrations of benzo[a]pyrene during winter months regularly exceeded the European limits. However, indicating within the larger urban area, the residents were at higher risk of developing cancer due to the combustion of residential solid fuel burning [14]. Air pollution episodes occurring during the winter months have been established to be attributable to an increased risk on human health, in the development of cancer during the lifetime [16]. Improved knowledge on sources of benzo[a]pyrene to improve air quality policies, can reduce emissions that are impacting upon health.

\subsubsection{Health Impacts on Children and Prenatal Exposure}

Research [15] estimated through the use of human respiratory tract disposition modelling, that there is a greater risk of infants and children developing lung cancer in comparison to adults. This increase may possibly be the developing physiology of a child. Children are more susceptible to the effects from air pollutants. A child's lung has not fully developed, and their bodyweight is much lesser than that of an adult. In addition children's height results in the child being closer to the ground level, consequently, inhaling the heavier pollutants [23]. The research [15], conducted assessed the risk of cancer which is attributable to polycyclic aromatic hydrocarbons exposure, consequent to the recent increase of residential solid fuel combustion. Exposure to polycyclic aromatic hydrocarbons such as benzo[a]pyrene, that have been released from residential solid fuel burning during the prenatal and early postnatal stages are of particular concern [24]. Research of when effects from pollutants start and if they continue to persist throughout childhood years [25], concluded that a foetus' exposure, resulted in significant association with height growth during childhood. The foetal brain and central nervous system are developing, thus sensitive to pollutants. Prenatal exposure to benzo[a]pyrene increases risk of developing anxi- 
ety, depression and attenuation problems later on in the child's life [24].

\subsection{Governmental Policy}

Globally levels of air pollution have led to Governments introducing legislation and policies to reduce harmful pollutants within their country. The European Union has set targets for a low-carbon economy by 2050, aiming for the Member States to be more climate-friendly and less energy consuming. Governmental efforts to reduce greenhouse gas emissions have resulted in many countries utilizing wood and biomass sources as a form of domestic heat. In addition to wood being renewable, it is deliberated to be an energy source that is carbon neutral. In countries where wood is in abundance, producing the energy requirements for their citizens is an established industry [26]. In concurrent research [27] indicated that, as a result of climate change and due to the security of future energy supplies, namely fossil fuels, there has been a resurge in the use of wood for residential heating. Governments have seen biomass to be an important resource in achieving a low-carbon economy. Throughout Europe, alternatives to fossil fuels have gained political and economic attention. The production of wood used for domestic residential heating has been increasing, due to fossil fuels contributing to, detrimental effect on the environment and human health [20]. Research on residential wood combustion [8], found that wood sources for residential heating are locally available in rural areas throughout mid-Europe. Wood is competitively priced in comparison to oil and gas. With divergence to those studies promoting the benefits of the utilization of wood as a clean energy source, the annual European air quality report details that, the exposure to benzo[a]pyrene has increased 21\% from 2003 to 2012. This increase has been associated with emissions released from the residential combustion of solid fuels, including wood [1]. Air pollution levels are a priority for international, national and local governments. Principally within the new European Member States, such as Poland, solid fuel combustion for domestic heating is widely used [15], resulting in countries producing high levels of pollutants and incurring breaching fines. This problem is not solely associated with Europe. A study conducted in New Zealand, evidenced high levels of particulate matter that was primarily attributable to residential solid fuel combustion. Within one of the cities, stringent intervention measures were implemented to manage the air quality issue. A residential heater replacement programme was instigated and a ban on new build dwellings installing solid fuel burners was introduced [28]. A similar approached intervention and financial incentive could be implemented within European countries.

\subsection{Seasonality of Residential Solid Fuel Burning}

From the 28 articles the author reviewed, 14 were related to the seasonal variation of pollutants resultant from residential solid fuel burning. A study within two urban sites [29], sampled the concentrations of benzo[a]pyrene, concluding that the winter average was higher than the annual European limit value. A similar study [30] was conducted at a rural background site, which sampled $\mathrm{PM}_{2.5}$ levels. Corresponding with the urban sites, during the winter period there was an increase in air pollutants resultant from residential solid fuel burning. Sampled pollutants were deemed to be three times higher than the summer period [30]. Governments believe that residential wood combustion as a source of domestic heating, signifies a renewable energy source of the future. However, wood combustion has been associated with increased concentrations of air pollutants in both urban and rural areas [29]. With the increasing costs associated with fossil fuels and other energy sources, there is a conception of a wood burning stove being an inexpensive and locally available energy source, residential areas may find an increase in installations [14]. Within Germany, there has been an increase in pollutants, resultant from residential solid fuel combustion. However, this is due to the increasing number of wood stoves being installed for domestic heating, as the number of open fire places has been decreasing [31]. The reviewed articles suggest that the majority of residential solid fuel combustion is occurring during the evenings and weekends throughout the winter months. In addition, it became apparent from the review of literature that the majority of dwellings, which had been seasonally burning solid fuel, were doing so as an additional secondary source of heating.

\section{Conclusion}

The reviewed studies illustrated the use of wood stoves as a form of domestic heating has become increasingly popular. In comparison, the use of open fire places as a form of heating has decreased. The sourced literature, evidences the increase of wood and biomass as domestic heating fuels, is resultant from governmental incentives. 
These incentives are to create a low-carbon, sustainable society. The literature sourced that the financial saving was a motivator in residents switching from oil and gas as a source of domestic heating, to wood burning stoves. Wood is renewable and is therefore deemed to be in abundance and inexpensive in comparison to fossil fuels such as coal, oil and gas. The systematic literature review also supported that the burning of residential solid fuel was seasonal specific, occurring mainly during evenings and weekends throughout the winter months. Fuel poverty may be apparent, as homeowners may be spending more than $10 \%$ of the household income heating their homes. Older heating systems tend to be less energy efficient [32]. Winter months are the coldest periods of the year, in accordance heating costs will be higher during these months. Subsequently, the use of residential solid fuel burning could be a domestic heating method correlated with that suffering fuel poverty, as an inexpensive way to heat the home. The review of literature indicated that there was an increase of air pollutants in both urban and rural sites, within developed countries. These are resultant from the domestic burning of solid fuels to heat the home. The literature sourced from the systematic review, supported that there was a gap within the body of knowledge. The gap was evidenced by the lack of scientific proof on the effects on the health of humans impacting from the different pollutants and their concentration levels. Of the 28 articles sourced, only eight articles made a direct association between residential solid fuel burning and thus the contributing adverse effects on human health. Due to the extensive variety both internal and external, contributing sources to air pollution within a dwelling, a definitive source of exposure is hard to evidence.

\section{References}

[1] European Environment Agency (2014) Air Quality in Europe-2014 Report.

[2] Kliucininkas, L., Krugly, E., Stasiulaitiene, I., Radziuniene, I., Prasauskas, T., Jonusas, A., Kauneliene, V. and Martuzevicius, D. (2014) Indoor-Outdoor Levels of Size Segregated Particulate Matter and Mono/Polycyclic Aromatic Hydrocarbons among Urban Areas Using Solid Fuels for Heating. Atmospheric Environment, 97, 83-93. http://dx.doi.org/10.1016/j.atmosenv.2014.08.010

[3] Kim, K., Jahan, S.A., Kabir, E. and Brown, R.J.C. (2013) A Review of Airborne Polycyclic Aromatic Hydrocarbons (PAHs) and Their Human Health Effects. Environment International, 60, 71-80. http://dx.doi.org/10.1016/j.envint.2013.07.019

[4] Happo, M.S., Uski, O., Jalava, P.I., Kelz, J., Brunner, T., Hakulinen, P., Mäki-Paakkanen, J., Kosma, V., Jokiniemi, J., Obernberger, I. and Hirvonen, M. (2013) Pulmonary Inflammation and Tissue Damage in the Mouse Lung after Exposure to PM Samples from Biomass Heating Appliances of Old and Modern Technologies. Science of the Total Environment, 443, 256-266. http://dx.doi.org/10.1016/j.scitotenv.2012.11.004

[5] Peltier, R.E., Cromar, K.R., Ma, Y., Fan, Z.T. and Lippmann, M. (2011) Spatial and Seasonal Distribution of Aerosol Chemical Components in New York City: (2) Road Dust and Other Tracers of Traffic-Generated Air Pollution. Journal of Exposure Science and Environmental Epidemiology, 21, 484-494. http://dx.doi.org/10.1038/jes.2011.15

[6] Gonçalves, C., Alves, C. and Pio, C. (2012) Inventory of Fine Particulate Organic Compound Emissions from Residential Wood Combustion in Portugal. Atmospheric Environment, 50, 297-306. http://dx.doi.org/10.1016/j.atmosenv.2011.12.013

[7] Kortelainen, M., Jokiniemi, J., Nuutinen, I., Torvela, T., Lamberg, H., Karhunen, T., Tissari, J. and Sippula, O. (2015) Ash Behaviour and Emission Formation in a Small-Scale Reciprocating-Grate Combustion Reactor Operated with Wood Chips, Reed Canary Grass and Barley Straw. Fuel, 143, 80-88. http://dx.doi.org/10.1016/j.fuel.2014.11.006

[8] Schmidl, C., Luisser, M., Padouvas, E., Lasselsberger, L., Rzaca, M., Ramirez-Santa Cruz, C., Handler, M., Peng, G., Bauer, H. and Puxbaum, H. (2011) Particulate and Gaseous Emissions from Manually and Automatically Fired Small Scale Combustion Systems. Atmospheric Environment, 45, 7443-7454. http://dx.doi.org/10.1016/j.atmosenv.2011.05.006

[9] Bølling, A.K., Pagels, J., Yttri, K.E., Barregard, L., Sallsten, G., Schwarze, P.E. and Boman, C. (2009) Health Effects of Residential Wood Smoke Particles: The Importance of Combustion Conditions and Physicochemical Particle Properties. Part. Fibre Toxicol, 6, 29.

[10] Kourtchev, I., Hellebust, S., Bell, J.M., O’Connor, I.P., Healy, R.M., Allanic, A., Healy, D., Wenger, J.C. and Sodeau, J.R. (2011) The Use of Polar Organic Compounds to Estimate the Contribution of Domestic Solid Fuel Combustion and Biogenic Sources to Ambient Levels of Organic Carbon and PM2.5 in Cork Harbour, Ireland. Science of the Total Environment, 409, 2143-2155. http://dx.doi.org/10.1016/j.scitotenv.2011.02.027

[11] Pietrogrande, M.C., Abbaszade, G., Schnelle-Kreis, J., Bacco, D., Mercuriali, M. and Zimmermann, R. (2011) Seasonal Variation and Source Estimation of Organic Compounds in Urban Aerosol of Augsburg, Germany. Environmental Pollution, 159, 1861-1868. http://dx.doi.org/10.1016/j.envpol.2011.03.023 
[12] Saarikoski, S.K., Sillanpää, M.K., Saarnio, K.M., Hillamo, R.E., Pennanen, A.S. and Salonen, R.O. (2008) Impact of Biomass Combustion on Urban Fine Particulate Matter in Central and Northern Europe. Water, Air, and Soil Pollution, 191, 265-277. http://dx.doi.org/10.1007/s11270-008-9623-1

[13] Umlauf, G., Christoph, E.H., Eisenreich, S.J., Mariani, G., Paradiž, B. and Vives, I. (2010) Seasonality of PCDD/Fs in the Ambient Air of Malopolska Region, Southern Poland. Environmental Science and Pollution Research, 17, 462469. http://dx.doi.org/10.1007/s11356-009-0215-4

[14] Alves, C., Nunes, T., Vicente, A., Gonçalves, C., Evtyugina, M., Marques, T., Pio, C. and Bate-Epey, F. (2014) Speciation of Organic Compounds in Aerosols from Urban Background Sites in the Winter Season. Atmospheric Research, 150, 57-68. http://dx.doi.org/10.1016/j.atmosres.2014.07.012

[15] Sarigiannis, D.A., Karakitsios, S.P., Zikopoulos, D., Nikolaki, S. and Kermenidou, M. (2015) Lung Cancer Risk from PAHs Emitted from Biomass Combustion. Environmental Research, 137, 147-156. http://dx.doi.org/10.1016/j.envres.2014.12.009

[16] Callén, M.S., López, J.M., Iturmendi, A. and Mastral, A.M. (2013) Nature and Sources of Particle Associated Polycyclic Aromatic Hydrocarbons (PAH) in the Atmospheric Environment of an Urban Area. Environmental Pollution, 183, 166-174. http://dx.doi.org/10.1016/j.envpol.2012.11.009

[17] Clancy, L., Goodman, P., Sinclair, H. and Dockery, D.W. (2002) Effect of Air-Pollution Control on Death Rates in Dublin, Ireland: An Intervention Study. The Lancet, 360, 1210-1214. http://dx.doi.org/10.1016/S0140-6736(02)11281-5

[18] Reisen, F., Meyer, C.P.(. and Keywood, M.D. (2013) Impact of Biomass Burning Sources on Seasonal Aerosol Air Quality. Atmospheric Environment, 67, 437-447. http://dx.doi.org/10.1016/j.atmosenv.2012.11.004

[19] Nordin, E.Z., Uski, O., Nyström, R., Jalava, P., Eriksson, A.C., Genberg, J., Roldin, P., Bergvall, C., Westerholm, R., Jokiniemi, J., Pagels, J.H., Boman, C. and Hirvonen, M. (2015) Influence of Ozone Initiated Processing on the Toxicity of Aerosol Particles from Small Scale Wood Combustion. Atmospheric Environment, 102, 282-289. http://dx.doi.org/10.1016/j.atmosenv.2014.11.068

[20] Haluza, D., Kaiser, A., Moshammer, H., Flandorfer, C., Kundi, M. and Neuberger, M. (2012) Estimated Health Impact of a Shift from Light Fuel to Residential Wood-Burning in Upper Austria. Journal of Exposure Science and Environmental Epidemiology, 22, 339-343. http://dx.doi.org/10.1038/jes.2012.27

[21] Riddervold, I.S., Bønløkke, J.H., Olin, A., Grønborg, T.K., Schlünssen, V., Skogstrand, K., Hougaard, D., Massling, A. and Sigsgaard, T. (2012) Effects of Wood Smoke Particles from Wood-Burning Stoves on the Respiratory Health of Atopic Humans. Part Fibre Toxicol, 9, 12. http://dx.doi.org/10.1186/1743-8977-9-12

[22] IARC (2010) Some Non-Heterocyclic Polycyclic Aromatic Hydrocarbons and Some Related Exposures. IARC Monogr. Eval. Carcinog. Risks Hum, 92, 1-853.

[23] WHO (2008) Outdoor Air Pollution Children’s Health and the Environment WHO Training Package for the Health Sector. World Health Organisation.

[24] Perera, F.P., Tang, D., Wang, S., Vishnevetsky, J., Zhang, B., Diaz, D., Camann, D. and Rauh, V. (2012) Prenatal Polycyclic Aromatic Hydrocarbon (PAH) Exposure and Child Behavior at Age 6-7 Years. Environ Health Perspect, 120, 921-926. http://dx.doi.org/10.1289/ehp.1104315

[25] Jedrychowski, W.A., Perera, F.P., Majewska, R., Mrozek-Budzyn, D., Mroz, E., Roen, E.L., Sowa, A. and Jacek, R. (2015) Depressed Height Gain of Children Associated with Intrauterine Exposure to Polycyclic Aromatic Hydrocarbons (PAH) and Heavy Metals: The Cohort Prospective Study. Environmental Research, 136, 141-147. http://dx.doi.org/10.1016/j.envres.2014.08.047

[26] Ghafghazi, S., Sowlati, T., Sokhansanj, S., Bi, X. and Melin, S. (2011) Particulate Matter Emissions from Combustion of wood In District Heating Applications. Renewable and Sustainable Energy Reviews, 15, 3019-3028. http://dx.doi.org/10.1016/j.rser.2011.04.001

[27] Williams, A., Jones, J.M., Ma, L. and Pourkashanian, M. (2012) Pollutants from the Combustion of Solid Biomass Fuels. Progress in Energy and Combustion Science, 38, 113-137. http://dx.doi.org/10.1016/j.pecs.2011.10.001

[28] Scott, A.J. and Scarrott, C. (2011) Impacts of Residential Heating Intervention Measures on Air Quality and Progress towards Targets in Christchurch and Timaru, New Zealand. Atmospheric Environment, 45, 2972-2980. http://dx.doi.org/10.1016/j.atmosenv.2010.09.008

[29] Piazzalunga, A., Anzano, M., Collina, E., Lasagni, M., Lollobrigida, F., Pannocchia, A., Fermo, P. and Pitea, D. (2013) Contribution of Wood Combustion to PAH and PCDD/F Concentrations in Two Urban Sites in Northern Italy. Journal of Aerosol Science, 56, 30-40. http://dx.doi.org/10.1016/j.jaerosci.2012.07.005

[30] Gilardoni, S., Vignati, E., Cavalli, F., Putaud, J.P., Larsen, B.R., Karl, M., Stenstroem, K., Genberg, J., Henne, S. and Dentener, F. (2011) Better Constraints on Sources of Carbonaceous Aerosols Using a Combined Super(14)C-Macro Tracer Analysis in a European Rural Background Site. 
[31] Brandt, C., Kunde, R., Dobmeier, B., Schnelle-Kreis, J., Orasche, J., Schmoeckel, G., Diemer, J., Zimmermann, R. and Gaderer, M. (2011) Ambient PM10 Concentrations from Wood Combustion-Emission Modeling and Dispersion Calculation for the City Area of Augsburg, Germany. Atmospheric Environment, 45, 3466-3474. http://dx.doi.org/10.1016/j.atmosenv.2011.01.075

[32] Fu, M., Kelly, J.A. and Clinch, J.P. (2014) Residential Solid Fuel Use: Modelling the Impacts and Policy Implications of Natural Resource Access, Temperature, Income, Gas Infrastructure and Government Regulation. Applied Geography, 52, 1-13. http://dx.doi.org/10.1016/j.apgeog.2014.04.007 